\title{
KADINSIZ ŞEHIR AYNAROZ: TARİH, MEKÂN VE YAŞAM
}

\author{
Abidin TEMIZER ${ }^{1}$
}

\begin{abstract}
Özet
Aynaroz, Güneydoğu Avrupa'da, Yunanistan'ın Selanik şehri yakınlarındaki Halkidiya Yarımadasında, Kassandra Parmakları diye bilinen ve Ege Denizi'ne doğru uzanan üç dar ve uzun yarımadanın en doğuda olanına verilen isimdir. Manastırlar şehri olarak bilinen Aynaroz'a, Rahip Athanasios tarafından kadın ve her türlü dişi hayvanın, hatta "sakalsız" erkeklerin dahi girmesi yasaklanmıştır. Söz konusu yasak makalenin yazıldığ 2011 yılında dahi devam etmektedir.

Bu makalede Aynaroz'un tarihçesi ve kadınsız bir hayatın şehrin sosyal, ekonomik ve güncel yaşamına etkisi incelenecektir. Konu ile ilgili başta Başbakanlık Osmanlı Arşivi belgeleri olmak üzere çok sayıda birinci elden kaynak kullanılmıştır.
\end{abstract}

Anahtar Kelimeler: Aynaroz, Kadınsız Şehir, Halkidi, Athos, Agion Oros

\begin{abstract}
Agion Oros is the name of the eastern side of three narrow and long peninsulas, which are known as Cassandra's Fingers and reach towards the Aegean Sea, that is located on the Halkidiya Peninsula near Thessaloniki of Greece in the Southeast Europe. Being known as the city of monasteries, Agion Oros was forbidden to welcome women and all species of female animals and even "beardless" men by the Priest Athanasios. This prohibition is also valid in year 2012, when this article was written.

This article will examine the effect of a womanless life in Agion Oros upon the social, economic and current life of the city. Regarding the subject, particularly the Premiership Ottoman Archive and a great number of first-hand resources were used.
\end{abstract}

Keywords: Agion Oros, Womanless City, Halkidi, Athos

\section{Giriş}

Her devrin ve yaşayışın kendine özgü mekân ve yaşam tasarrufu vardır ${ }^{2}$. İnsan ise mekâna kendi şeklini ve canlılığını veren bir varlıktır. Öyle ki mekân, toplum ruhunun somut hale gelmiş bir ifadesidir. Bu yüzden her mekân, bir toplum için sosyo-kültürel tanımlayıcı olarak düşünülmelidir. Mekândan yola çıkarak o yerin

${ }^{1}$ Balıkesir Üniversitesi, Atatürk İlkeleri ve İnkılâp Tarihi Bölümü, Çağış Kampüsü/Balıkesir, abidintemizer@hotmail.com.

${ }^{2}$ Ahmet Hamdi Tanpınar, Saatleri Ayarlama Enstitüsü, Dergâh Yayınları, İstanbul 2005, s. 133. 
insanları hakkında kanaat sahibi olunabilir. Bu bağlamda insan da bir mekândır ve bulunduğu mekândaki nesneye ruhunu katarak onu canlı bir şahsiyet haline getirebilir ${ }^{3}$.

$\mathrm{Bu}$ çalışmada, yukarıda ifade edilen cümlelere denk düşen bir mekân; manastırlar şehri Aynaroz ele alınacaktır. Aynaroz'un tarihi, nüfusu, manastırları ve gündelik yaşamı gibi konulara değinilecektir. Kadınların bulunmadığı, hatta uğramalarının dahî yasak olduğu ve nüfusun neredeyse büyük çoğunluğunu papazların oluşturduğu bu şehirde "papazlar nasıl yaşardı?” sorusuna cevap aranacaktır. Mekânın ve icra edilen mesleğin, yemek kültürüne, cinselliğe, üretim ve tüketim üzerine etkileri çalışmanın ana hedefi olacaktır.

\section{Aynaroz'un Tarihçesi}

Aynaroz adı, Grek dilindeki Agion Oros isminin değişmesiyle Türkçe'ye geçmiştir. Aynaroz'un İtalyan dilindeki karşılığı ise Monte Santo'dur' ${ }^{4}$. Hem Monte Santo hem de Agion Oros isimleri Holy Mountain (Kutsal Dağ) anlamını taşımaktadır ${ }^{5}$.

Aynaroz, Güneydoğu Avrupa'da, Yunanistan'ın Selanik şehri yakınlarındaki Halkidiya Yarımadasında, Kassandra Parmakları diye bilinen ve Ege Denizi'ne doğru uzanan üç dar ve uzun yarımadanın en doğuda olanına verilen isimdir ${ }^{6}$.

Manastırlar şehri Aynaroz'da ilkçağlarda bir yerleşme olup olmadığına dair kesin bir bilgi yoktur. Ancak Helenistik devrinde burada yerleşim yerlerinin bulunduğunu gösteren bazı küçük izler mevcuttur. Bizans devrinde adanın dik yarlarında yeşillikler arasındaki mağara ve kovuklar uzun süre yalnız, dünyevî âlemden uzak yaşamak isteyen "târik-i dünyâ" (münzevi) keşişlerin barınağ1

${ }^{3}$ Ruhi İnan, "Karşılaştırmalı Sosyo-Kültürel Bir Mekân Poetiği: Akif' in Mahalle Kahvesi ve Esâfil-i Şark”, Uluslararası Mehmet Akif Ersoy Sempozyumu, 11-13 Mart 2011 Balıkesir Bildiriler Kitabl, Balıkesir 2011, s.241.

${ }^{4}$ G.W. Samson, Elements of Art Criticism, Philadelphia 1967, s.596.

${ }^{5}$ George Henry Townsend, A Manual of Dates: a Dictionary of Reference, Frederick Warne\&Co., London 1867, s.577.

${ }^{6}$ Meral Metin, XIX. Y.Y.da Osmanll Devleti'nde Aynaroz Adasl, Aynaroz Ruhbanlarl ve Rum Ísyanları, Yayımlanmamış Yüksek Lisans Tezi), Kayseri: Erciyes Üniversitesi, Sosyal Bilimler Enstitüsü, Tarih Anabilim Dalı, Kayseri 2010, s. 65. 
olmuştur. Kovolos adında bir keşiş, Hierissos şehri civarında ilk teşkilatlı manastırı kurmuş ve kısa süre içinde bu dinî tesis, yarımadanın tepelerinde dağınık halde bulunan keşişlerle kuzeydeki kıta toprağında küçük topluluklar halinde yaşayan ve tarımla uğraşan keşişleri birleştirmiştir. IX. yüzyıl sonlarında ise bütün Ortodoks âleminde Aynaroz'un şöhreti duyulmuştur. X. yüzyıl başlarında bu dinî topluluğun idare merkezi bugünkü Karyes’te toplanmış, buraya bir kilise ile idarî işler başkanı (protos) için bir makam (protaton) ve memur keşişler için de evler yapılmıştır ${ }^{7}$.

Bizans Kralı Nikephoros Phokas 963 yılında yarımadanın güneybatı kıyısında Lavra Manastırı'nı kurmuştur. Ancak bir suikast sonucu öldürülmesi kralın inşa ettirdiği Lavra Manastırı'na çekilmesini engellemiştir. Bununla birlikte Lavra, bir başrahip idaresinde pek çok keşişin barındığı bir manastır olarak gelişmiştir. 1045 yılına gelindiğinde Lavra'da 300 keşişin yaşadığı bilinmektedir ${ }^{8}$.

1046'da İmparator Kostantinos, Aynaroz Cumhuriyeti'ne bazı haklar vermiştir' 9 Buna göre;

1. Gemi inşa edilebilecek, İstanbul'a zeytin, şarap ve kömür nakledilebilecek,

2. Manastırlara ait mevasi (davar) her merada gezebilecek,

3. Ormanlardan alınan cüzi miktardaki vergi dışında vergi verilmeyecektir.

Bu haklar önceleri sadece Lavra Manastırı için geçerli iken İmparator I.Aleksi ve II. Yoanis zamanlarında genel manastırlara da tanınmıştır. 1195'ten 1203 senesine kadar tahtta kalan III.Aleksi Islafi zamanında ise Rus ve Sirpların manastır, mezra, ve hücreler inşa edebilmelerine ruhsat verilmiştir ${ }^{10}$. XII. yüzyılda çeşitli

\footnotetext{
${ }^{7}$ Semavi Eyice, “Aynaroz”, Türkiye Diyanet Vakfi İslam Ansiklopedisi (DİA), C.4, İstanbul 1991, s.267.

${ }^{8}$ Semavi Eyice, a.g.m., s.267.

9 Musa Kazım, "Aynaroz'un Tarihçesi”, Tarihi Osmanî Encümeni Mecmuası, Cilt 4, 19.Cüz, 1 Nisan 1339, s.1195.

${ }^{10}$ Musa Kazım, a.g.e., s. 1195.
} 
Slav milletlerine mensup keşişlerle Ruslar, Bulgarlar ve Sırplar Aynaroz'a gelerek burada manastırlar kurmuşlardır ${ }^{11}$.

XIII. yüzyılda IV. Haçlı Seferi ile Latinlerin İstanbul'u işgal ederek Bizans Devleti'ni parçalaması sonucu yaşanan sıkıntılardan Aynaroz da kendi payına düşeni yaşamıştır. Öncelikle Aynaroz'un imtiyazlı statüsüne son verilmek istenmiş, ancak bunda başarılı olunamamıştır. Aynaroz bu dönemde Haçlı Seferi'nin yarattığı ortamı fırsat bilen korsan ve eşkıyaların saldırılarına maruz kalmıştır. Ruhbanlar söz konusu saldırılardan korunmak için iki yola başvurmuşlardır. İlk olarak çok sayıda kale yapmışlar, ancak kale yapımı saldırıları önleyemeyince ruhbanlar ikinci çare olarak Papa III. Innocentius'dan yardım talebinde bulunmuşlardır. Bu talebi firsat bilen Papa, 1261'de Michel Paleogolos'u Şark ve Garp kiliselerini birleştirmek üzere İznik’ten Aynaroz’a göndermiştir. Ancak Michel Paleogolos bu görevinde başarılı olamamıştır.

Latinlerin Bizans'tan atıldığ 1261'den 1312 yılına kadar ki sürede Aynaroz'un ömrü müdahalelerle geçmiştir ${ }^{12}$. II. Andronikos (1282-1328) arazilerini genişleterek Aynaroz'a yeni haklar tanımış ve Aynaroz manastırlarını 1312'de İstanbul Patrikhanesi'ne bağlamıştır ${ }^{13}$. Bu tarihte Protos denilen yöneticinin seçimi yeniden Aynaroz ahalisine bırakılmıştır ${ }^{14}$. Böylece 1312 'den 1351 'e kadar Aynaroz Adası önceki dönemin aksine huzur içinde bir 39 yıl geçirmiştir ${ }^{15}$.

Bizans İmparatoru Manuel Paleologos, patrik efendiler ile Ortodoksların muhabbetini kazanmak için 1392'de Aynaroz 'un imtiyazlı statülerini kabul etmiştir. Bu imtiyaz Osmanlı hâkimiyetine kadar devam etmiştir ${ }^{16}$.

1430 yılına gelindiğinde Selanik Osmanlılar tarafından fethedilince Aynaroz da Osmanlı idaresine geçmiştir ${ }^{17}$. Osmanlı döneminde burada Türk idaresi,

\footnotetext{
${ }^{11}$ Semavi Eyice, a.g.m., s.267.

12 Musa Kazim, a.g.e., s.119-1197.

${ }^{13}$ Semavi Eyice, a.g.m., s.267.

${ }^{14}$ Önder Kaya, Tarihin Gör Dediği, Yeditepe Yayınları, İstanbul 2006, s.140.

${ }^{15}$ Musa Kazım, a.g.e., s. 1197.

${ }_{16}^{16}$ Musa Kazım, a.g.e., s.1197-1198.

${ }^{17}$ Semavi Eyice, a.g.m., s.267.
} 
Bostancıbaşı'ya bağlı olarak Karyes'te oturan bir haseki tarafından temsil edilmiştir $^{18}$.

Aynaroz'daki din adamları Türk hâkimiyetinde bazı yeni haklar elde etmişlerdir. Bizans tarihçisi F. Dölger'in ifadesiyle “...Türk Sultanlarl, Aynaroz’un eski bağımsızlık haklarını yalnız tanımakla kalmamışlar, aynı zamanda onlara yeni haklar da bağışlamışlardır." Aynaroz'u fermanları ile koruyan Fatih Sultan Mehmed ve Yavuz Sultan Selim gibi hemen hemen bütün padişahlar manastırları vergi karşısında himaye etmişlerdir ${ }^{19}$. Aynaroz manastırları tıpkı diğer manastırlar gibi Osmanlı hâkimiyeti boyunca vergilerini ödemişlerdir. Ancak Aynaroz'daki manastırların vergi ödeme şekilleri de dönem dönem farklılık göstermiştir. Çoğunlukla cizye vergisi din adamları tarafından toplanıp teslim edilirken, bazen bu vergi toplanan diğer vergilerle beraber gönderilmiştir. Örneğin, Sultan Abdülmecid zamanında manastırlarının güvenliği için istihdam edilen askerlere ödenen maaşlar, Aynaroz'un senelik vergisine ilave edilerek alınmıştır ${ }^{20}$.

Osmanlı idaresinde Aynaroz'a Hıristiyan halktan, Eflak, Boğdan ve Rusya'dan büyük bağışlar gelmiştir. Ancak XVII. yüzyılın başlarında fazla bir otoritesi kalmayan protos ortadan kalkmış, büyük manastırlar da fakirleşmeye başlamışlardır. Buna karşın Aynaroz XVIII. yüzyılın ortalarında yeniden parlamaya başlamıştır. 1743'te Vatopedi Manastırı'na komşu bir akademi kurulmuştur. Semavi Eyice, "bu akademinin her türlü yeniliğe karşı olan keşişlerin baskısı sonucu kapandığını” yazmaktadır ${ }^{21}$. Başbakanlık Osmanlı Arşivi'nde yer alan bir belgede Vatopedi'de bir okulun varlı̆̆ından bahsedilmekte ancak okulda eğitim verilip verilmediği konusuna değinilmemektedir ${ }^{22}$. Her şeye rağmen Aynaroz Adası'nda, XVIII. yüzyılda yaşanan gelişmeler milli fikirlerin doğmasına katkıda bulunmuştur. 1762'de Bulgar milliyetçiliğinin babası sayılan

\footnotetext{
${ }^{18}$ Semavi Eyice, a.g.m., s.268.

19 Semavi Eyice, a.g.m., s.267; Fatih Sultan Mehmed'in Aynaroz'a verdiği söz konusu ferman bugün Simonos Petra Manastırı'nda bulunmaktadır.

${ }^{20}$ BOA, A. MKT. NZD, Nr.88/76, Tarih: 27/Za/1269 (1 Ekim 1853).

${ }^{21}$ Semavi Eyice, a.g.m., s.267-268.

${ }^{22}$ BOA, A. DVN. KLS.d., Nr.930, Tarih: Receb 1237 (Mart/Nisan 1822).
} 
Paissij Hilandersky, Aynaroz'daki Hilandariu (Hilander) Manastırı'nda ilk Slavyan-Bulgar tarihini popüler bir dil ve üslupla kaleme almıştır ${ }^{23}$.

XVIII. yüzyılda Aynaroz'da yukarıda değindiğimiz gelişmelerin yanı sıra idarî alanda da bazı gelişmeler yaşanmıştır. 1783'te eski Protos'u canlandıran bir idare sistemine gidilerek büyük manastırların 20 temsilcisinden kurulan bir meclis, Aynaroz Manastır Cumhuriyeti'nin idaresini ele almıştır ${ }^{24}$. Meclisin 20 temsilciden oluşmasının nedeni bu dönemde Aynaroz Adası'nda 20 adet manastır bulunmasıdır. $\mathrm{Bu}$ durumda her manastırdan birer kişi mecliste bağlı olduğu manastırı temsil etmektedir ${ }^{25}$.

XIX. yüzyılda buradaki yabancı manastırlarda milliyetçilik hareketleri ön plana çıkmaya başlamıştır. Önceleri 18 Yunan manastırına karşılık sadece Sırplara ait Hilandariu ve Bulgarlara ait Zografu Manastırı varken, 1875'te Ruslar, Rusiko (Agiu Panteleimonos) Manastırı'na hâkim olarak meclise girme hakkını elde etmişlerdir ${ }^{26}$.

1430 yılında başlayan Osmanlı hâkimiyeti 20. yüzyılın başına kadar devam etmiştir. 1324 (1906/1907) Tarihli Selanik Vilâyet Salnamesi'ne göre Aynaroz Selanik Merkez Sancağı'na bağlı bir kaza hüviyetindedir ${ }^{27} .1912$ yılı Kasım ayında Balkan Savaşları neticesinde Yunan ordusu Aynaroz'a girerek Osmanlı'nın buradaki idaresine son vermiştir. Aynaroz, Yunanistan hâkimiyeti döneminde de müstakil idaresini kabul ettirmiş, bu nedenle yarımada bağımsız olarak kalabilmiştir ${ }^{28}$.

\section{Kadınsız Mekân Aynaroz Manastırları ve Nüfusu}

\footnotetext{
23 İlber Ortaylı, Imparatorluğun En Uzun Yüzyılı, İletişim Yayınları, İstanbul 2006, s.67.

${ }^{24}$ Semavi Eyice, a.g.m., s.268.

${ }^{25}$ BOA, C. ADL, Nr. 71/4289, Tarih: 04/B/1225 (5 Ağustos 1810); BOA, HR. MKT, Nr. 20/13, Tarih:11/Ca/1264 (16 Nisan 1848).

${ }^{26}$ Semavi Eyice, a.g.m., s. 268.

271324 tarihli Selanik Vilayet Salnamesi, s.5.

${ }^{28}$ Semavi Eyice, a.g.m., s.268.
} 
Aynaroz Adası'ndaki ilk teşkilatlı manastır Kolovos adında bir keşişin Hierissos şehri civarında kurduğu manastırdır ${ }^{29}$.

Bizans Kralı Nikephoros Phokas da dostu Rahip Athanasios aracılığı ile yarımadanın güneybatı kıyısında Larva Manastırı'nı kurmuştur (963-969) ${ }^{30}$. Bu dönemden itibaren Aynaroz'da manastır sayısı giderek artmıştır.

Değişik milletlerden 1.000 civarında Ortodoks papazı yarımadanın en yüksek noktası olan Athos Dağı yamaçlarındaki manastır, kilise ve dağ evlerinde yaşamaktadır. Kutsal Athos Dağı'nın en parlak döneminin yaşandığı 15. yüzyılda ise her birinde biner kesiş bulunan 30 kadar Yunan, Sırp, Bulgar Ortodoks manastırının olduğu kayıtlarda yer almıştır ${ }^{31}$.

XVI. yüzyıl başlarında Piri Reis, bu yıllarda Aynaroz'da on dokuzu kıyıda olmak üzere 60 kadar manastır bulunduğunu yazmıştır ${ }^{32}$.

Evliya Çelebi ise 17. yüzyılın ikinci yarısında Aynaroz Adasında "366 adet manastır" olduğunu yazmaktadır ${ }^{33}$. Evliya Çelebi'nin 366 olarak verdiği rakam manastırlardaki kilise ve diğer binaların tamamını içeriyor olmalıdır.

G. W. Samson 1828 yılı öncesinde Aynaroz'da 22 manastır ve 4 binin üzerinde keşiş olduğunu yazmıştır ${ }^{34}$. Ancak Başbakanlık Osmanlı Arşivi’nde bulunan bir belgeye göre 1822 yılında Aynaroz'da yirmi manastır vardır. Bu manastırlara ait oda, kilise, çeşme gibi bilgileri içeren tablo şu şekildedir ${ }^{35}$ :

\section{MANASTIRLAR DÂHILIINDE}

Katlarda Mutfak ve Tuvalet Harici Oda: 4439

Üzeri Kurşun Sagîr ve Kebîr Kilise: 191

Kârgîr Kuleler: 32

\footnotetext{
${ }^{29}$ Semavi Eyice, a.g.m., s. 267.

${ }^{30}$ Semavi Eyice, a.g.m., s. 268.

${ }^{31}$ Meral Metin, a.g.e., s.64.

${ }^{32}$ Semavi Eyice, a.g.m., s. 267.

${ }^{33}$ Evliya Çelebi Seyahatnamesi, Cilt: 8, Haz. Seyit Ali Karaman vd., YKY, İstanbul 2003, s.65.

${ }^{34}$ G. W. Samson, a.g.e., s.596.

${ }^{35}$ BOA, A. DVN. KLS.d., Nr.930, Tarih: Receb 1237 (Mart/Nisan 1822).
} 
Çeşme: 52

Kuyu: 17

Değirmen: 29

Ekmek Fırını:38

MANASTIRLAR HARÍCINDE

Kule: 18

Çeşme: 80

Hane(?)ve Konak: $934+95 \quad$ (Dermanastırın $\quad$ Evleri) $=1029$ (Ziyade olmak muhtemeldir)

Sagîr Kebîr Kilise:720+73 (ziyade olmak ihtimaldir) $=793$

Değirmen:16 (ziyade olmak ihtimaldir)

1860'lara gelindiğinde Aynaroz'da 20 manastır varlı̆̆ını sürdürürken bu manastırlarda sekiz binin üzerinde keşiş bulunmaktadır ${ }^{36}$.

1877 yılında Aynaroz'daki manastır sayısı hala $20^{\prime} \mathrm{dir}^{37}$. Bu manastırlar ve nüfusları aşağıdaki tabloda gösterildiği gibidir ${ }^{38}$ :

\begin{tabular}{|l|c|c|}
\hline Manastır & Keşiş Nüfusu & Avam Takımı \\
\hline Lavra Manastırı (Agiu-Aya- & 537 & 66 \\
\hline $\begin{array}{l}\text { Rusiko } \\
\text { Panteleimonos) Manastırı }\end{array}$ & 568 & 14 \\
\hline Vatopedi Manastırı & 445 & 66 \\
\hline
\end{tabular}

${ }^{36}$ M. Pierce, The Cottage Cyclopedia of History and Biography, Case Lockwood\&Brainard, Hartford, Cann, Chicago 1969, s.81.

${ }^{37}$ BOA, I. $D H$, Nr.756/61687-2, Tarih: 26/N/1294 (4 Ekim 1877).

${ }^{38}$ BOA, $I$. DH, Nr.756/61687-2, Tarih 26/N/1294 (4 Ekim 1877). 


\begin{tabular}{|c|c|c|}
\hline Pantokratoros Manastır1 & 290 & 47 \\
\hline İviron Manastır1 & 226 & 43 \\
\hline Agiu (Aya) Pavlu Manastırı & 215 & 11 \\
\hline Hilandariu (Hilander) Manastırı & 177 & 27 \\
\hline Kutlumusiu Manastırı & 135 & 52 \\
\hline Ksenofondos Manastır1 & 122 & 18 \\
\hline Esfigmenu Manastırı & 105 & 15 \\
\hline Dionysiu Manastırı & 102 & 5 \\
\hline Ksiropotamu Manastırı & 98 & 29 \\
\hline Filoteu Manastırı & 92 & 15 \\
\hline Karakalu Manastırı & 88 & 18 \\
\hline Zografu Manastırı & 87 & 28 \\
\hline Gorigoriu Manastır1 & 86 & 13 \\
\hline Simonos Petra Manastırı & 71 & 29 \\
\hline Stavronikita Manastırı & 60 & 11 \\
\hline Dohiariu Manastırı & 53 & 17 \\
\hline Konstamonitou Manastırı & 43 & 8 \\
\hline TOPLAM & 3.600 & 532 \\
\hline
\end{tabular}

1877 y1lında Aynaroz'daki 20 manastırda 3.600'ü keşiş olmak üzere 4.132 kişi yaşamaktadır. En fazla nüfusa sahip iki manastırdan ilki Larva, ikincisi Agiu 
Panteleimonos (Rusiko) manastırlarıdır. En az nüfus ise Konstamonitou Manastırı'nda yaşamaktadır.

Aynaroz'daki manastırlarda bu dönemde Rusların ektisi oldukça fazla hissedilmektedir. Mesela, Aynaroz'daki en büyük manastırlardan olan Agiu Panteleimonos manastırında ağırlıklı olarak Rus keşişler mütemekkin olup Manastırın başrahibi de (gomenus) Rus’tur. Söz konusu manastırda Rusların yanı sıra birkaç Rum rahip de yaşamaktadır. Ancak bunlar da çoğunluğu elinde bulunduran Rusların fikirleri doğrultusunda hareket etmektedirler. $\mathrm{Bu}$ hizmetlerinin karşılığını da almışlardır. Örneğin Agiu Panteleimonos Manastırı'nın şubelerini zapt etmekte Ruslara yardımcı olan manastırın Rum piskoposuna Ruslar tarafindan Karyes’te bir saray inşa edilmiştir. Rum Piskopos, Aynaroz'da bulunan diğer manastırların Rum rahiplerini iğfal eğmek için Ruslar tarafından baskı unsuru olarak kullanılmıştır ${ }^{39}$.

Rusların etkili oldukları bir diğer manastır ise Vatopedi Manastırı'dır. Ruslar bu manastırı bir rahipten satın almışlardır. Satın alındığı dönemde Vatopedi Manastırı'nda yalnızca yirmi beş otuz civarında Rus rahip iskân edebiliyorken, manastırın alımından sonra buradaki Rus rahip nüfusu birden artmıştır. Oysaki söz konusu manastır, buradaki Rus nüfusunun arttırılmaması şartı ile satılmıştı. $\mathrm{Bu}$ şarta riayet etmeyen Ruslar manastırdaki rahip nüfusunu hızlı bir şsekilde arttırmışlardır. Aynaroz Adasındaki Agiu Pavlu, Agiu Panteleimonos, Vatopedi, Pantokratoros, Kutlumusiu, Hilandariu ve Zografu manastırlarındaki Rus nüfusu bu dönemde iki bini aşmıştır ${ }^{40}$.

Rus rahipleri Yunan rahipler üzerinde etkili oldukları kadar Bulgar rahipler üzerinde de etkili olmuşlardır. Hilandariu ile Zografu adlı Bulgar manastırlarındaki rahipler de Ruslarla birlikte hareket ederek Rus rahiplerin politikasına tabiiyet etmişlerdir ${ }^{41}$.

\footnotetext{
${ }^{39}$ BOA, I. $D H$, Nr.756/61687-2, Tarih: 26/N/1294 (4 Ekim 1877).

${ }^{40}$ BOA, I. DH, Nr.756/61687-2, Tarih: 26/N/1294 (4 Ekim 1877).

${ }^{41}$ BOA, I. $D H$, Nr.756/61687-2, Tarih: 26/N/1294 (4 Ekim 1877).
} 
1877 y1lı itibarıyla Aynaroz Adası'nda bulunan 20 manastırdan on yedisi Rum, ikisi Bulgar ve biri Rus manastırıdır ${ }^{42}$. Bunlardan; Dionysiu Manastırı bir Rum manastırı olup, burada 90 Rum keşiş bulunmaktadır. Manastıra bağlı dört kilise ve beş kulede otuz Rum keşiş bulunmaktadır ${ }^{43}$.

Gorigoriu Manastırı bir Rum manastırıdır. Manastırda 80 Rum keşiş bulunmaktadır. Bu manastıra bağlı dört kilisede 17 Rum keşiş, dört kulübede ise sekiz Rum keşiş bulunmaktadır ${ }^{44}$.

Simonos Petra Manastırı da Rum manastırı olup, bu manastırda 90 Rum keşiş bulunmaktadır. Manastıra bağlı dört kilisede 18 ve dört kulübede 11 Rum keşiş vardir ${ }^{45}$.

Ksiropotamu Manastırı bir Rum manastırıdır. Söz konusu manastırda 120 Rum keşiş bulunmaktadır. Manastırın tasarrufunda bulunan dört kilisede 24 ve üç kulübede sekiz Rum keşiş vardır ${ }^{46}$.

Agiu Panteleimonos (Rusiko) Manastırı Rum ve Ruslardan oluşmaktadır. Rusların toplamı 400, Rumların 180, Bulgarların ise 25 keşiştir $^{47}$.

Ksenofondos Manastırı da Rum manastırı olup, bu manastırın 85 Rum keşişi bulunmaktadır. Manastırın mutasarrıf olduğu kiliselerde 80 Rum keşiş vardır ${ }^{48}$.

Dohiariu Manastırı Rum manastırıdır. Burada 85 Rum keşiş bulunmaktadır. $\mathrm{Bu}$ manastırın mutasarrıf olduğu üç kilisede 20 Rum keşiş vardır ${ }^{49}$.

Konstamonitou Manastırı Rum manastırıdır. Burada 55 Rum keşiş bulunmaktadır. $\mathrm{Bu}$ manastırın mutasarrıf olduğu 4 kilisede 14 Rum keşiş vardır ${ }^{50}$.

\footnotetext{
42 BOA, I. DH, Nr.756/61687-2, Tarih: 26/N/1294 (4 Ekim 1877).

${ }^{43}$ BOA, I. $D H$, Nr.756/61687-2, Tarih: 26/N/1294 (4 Ekim 1877).

${ }^{44}$ BOA, I. $D H$, Nr.756/61687-2, Tarih: 26/N/1294 (4 Ekim 1877).

${ }^{45}$ BOA, $\dot{I}$. $D H$, Nr.756/61687-2, Tarih: 26/N/1294 (4 Ekim 1877).

${ }^{46}$ BOA, $\dot{I}$. $D H$, Nr.756/61687-2, Tarih: 26/N/1294 (4 Ekim 1877).

${ }^{47}$ BOA, I. DH, Nr.756/61687-2, Tarih: 26/N/1294 (4 Ekim 1877).

${ }^{48}$ BOA, I. DH, Nr.756/61687-2, Tarih: 26/N/1294 (4 Ekim 1877).

${ }^{49}$ BOA, I. $D H$, Nr.756/61687-2, Tarih: 26/N/1294 (4 Ekim 1877).
} 
Kutlumusiu Manastırı Rum manastırıdır. Bu manastırda 85 Rum keşiş bulunmaktadır. Bu manastırın mutasarrıf olduğu 36 bab-1 kulübelerde 67 ve 16 kilisede 40 Rum keşiş vardır ${ }^{51}$.

Zografu Manastırı ise bir Bulgar manastırıdır. Burada 250 Bulgar keşiş bulunmaktadır $\mathrm{Bu}$ manastırın mutasarrıf olduğu 5 kilisede 25 Rum ve Bulgar keşiş vardir ${ }^{52}$.

1877 yılı itibariyle Aynaroz'daki manastırların ruhban sınıfının milletlere göre dağlımı şu şekildedir ${ }^{53}$ :

\begin{tabular}{|l|c|}
\hline \multicolumn{1}{|c|}{ Milliyet } & Nüfus \\
\hline Rum & 3.357 \\
\hline Sırp ve Bulgar & 593 \\
\hline Rus & 1.035 \\
\hline Ulah ve Buğdan & 252 \\
\hline Gürcü & 10 \\
\hline Diğer & 300 \\
\hline TOPLAM & $\mathbf{5 . 5 4 7}$ \\
\hline
\end{tabular}

Aynaroz'un bu dönemdeki 5.547 kişilik ruhban nüfusuna ek olarak Görice, Kisbe ve Nasic kasabalarından olup yaklaşık üç bin keresteci, kömürcü ve dülger amele

\footnotetext{
${ }^{50}$ BOA, I. $D H$, Nr.756/61687-2, Tarih: 26/N/1294 (4 Ekim 1877).

${ }^{51}$ BOA, I. $D H$, Nr.756/61687-2, Tarih: 26/N/1294 (4 Ekim 1877).

${ }^{52}$ BOA, $I . D H$, Nr.756/61687-2, Tarih: 26/N/1294 (4 Ekim 1877).

${ }^{53}$ BOA, I. $D H$, Nr.756/61687-2, Tarih: 26/N/1294 (4 Ekim 1877).
} 
de bulunmaktadır ${ }^{54}$. Bu durumda Aynaroz'un 1877 yılı toplam nüfusu yaklaşık 8.747 civarındadır.

H. 1299 (1881/1882) tarihli Selanik Vilayet Salnamesi'ne göre bu dönemde Aynaroz'da 28 Manastır bulunmaktadır. 7-8 bin civarındaki nüfusu ise papaz ve keşiş gibi din adamlarından oluşmaktadır. 200'den fazla hane ve 100 dükkân bulunmaktadır. Manastırların, Selanik Sancağı dâhilinde 58 kıta çiftliği bulunmaktadır. Manastırlarda bulunan din adamları tarım ile uğraşmaktadırlar. ${ }^{55}$ 1893/1894 y1lı verilerine göre Aynaroz'un nüfusu ve nüfusun özellikleri şu şekildedir ${ }^{56}$ :

\begin{tabular}{|c|c|c|c|c|c|}
\hline \multirow{3}{*}{$\begin{array}{l}\text { Cemaat } \\
\text { İsimleri }\end{array}$} & \multirow{3}{*}{$\begin{array}{l}\text { Genel } \\
\text { Toplam }\end{array}$} & \multicolumn{4}{|c|}{ Mevcut Nüfusu } \\
\hline & & \multicolumn{2}{|c|}{ Yerli } & \multicolumn{2}{|c|}{ Yabanc1 } \\
\hline & & Erkek & Kadın & Erkek & Kadın \\
\hline İslâm & 57 & & & 57 & \\
\hline Rum & 4131 & 2589 & & 1542 & \\
\hline Bulgar & 3313 & 3022 & & 291 & \\
\hline Yabancilar & 137 & & & 137 & \\
\hline Toplam & 7.638 & 5.611 & & 2.027 & \\
\hline
\end{tabular}

\footnotetext{
${ }^{54}$ BOA, I. DH, Nr.756/61687-2, Tarih: 26/N/1294 (4 Ekim 1877).

551299 Tarihli Selanik Vilayet Salnamesi, s. 125.

56 Mustafa Balcı, Selanik Düştü, Selanik'in Kaybediliş Öyküsü, Kesit Yayınları, İstanbul 2010, s.262.
} 
Tabloya göre Aynaroz'un 1893/1894 yılı nüfusu 7.638'dir. Nüfusun çoğunluğu Ortodoks olan Rum ve Bulgarlardan oluşmaktadır. Aynaroz'da bulunan 57 kişilik İslam nüfusu muhtemelen bölgede görevli Osmanlı memur ve askerleridir. Tabloda dikkat edilmesi gereken bir diğer husus nüfusun tamamının erkek olmasıdır. Bu durum 1045 yılında konulmuş olan ve o tarihten itibaren süregelen bir yasaktan kaynaklanmaktadır. Rahip Athanasios 1045'te Aynaroz'a kadın ve her türlü dişi hayvan, hatta "sakalsız" erkeklerin dahi girmesini yasaklamıştır" Şeytan ve yılanla özdeş sayılan kadın, özellikle Aynaroz’a sığınan çilekeş papazlara göre yeryüzündeki en büyük günahın temsilcileridir. $\mathrm{Bu}$ nedenle yüzyıllardır bu manastıra kadın ayağı değmemiştir. Kadını uğursuz sayan bu kesişler Aynaroz'a kadın girerse intihar edeceklerini beyan etmişlerdir ${ }^{58}$.

Kadının giremediği ve her türlü işin din adamları tarafından yapıldığg Aynaroz'un H.1317 (1899-1900) yılı vergileri şöyledir ${ }^{59}$ :

Maktu vergi: 72.000 kuruş,

Ağnam vergisi: 20.322 kuruş

Canavar (domuz) vergisi: 1.015 kuruştur.

1320 (1902-1903) tarihli Selanik Vilayet Salnamesi'ne göre Aynaroz kazasının nüfusu 8.000 civarındadır. Bu nüfusun yaklaşık 6.000 kadarını din adamları, gerisini de işçi vs. oluşturmaktadır. Burada 55 keşişhane, 1 kilise ve 1 Rum mektebi vardır. Tarım ürünlerinden zeytin ve fındık bolca yetiştirilmekte, bazı rahipler ise ağaçtan kaşık, sedeften tespih ve kalimafka denilen kalpak imal etmektedirler ${ }^{60}$.

20. yüzyılın başlarında Aynaroz'da 20 manastır ve 500'den fazla kilise ve papazlara mahsus hücreler bulunmaktadır. Bu manastır, kilise ve hücrelerde 3.615

${ }_{58}^{57}$ Semavi Eyice, a.g.m., s. 267.

${ }_{58}^{5}$ Meral Metin, a.g.t., s.68-69.

591320 tarihli Selanik Vilayet Salnamesi, s.492.

${ }^{60} 1320$ tarihli Selanik Vilayet Salnamesi, s.492. 
Rus, 3.207 Rum, 340 Bulgar, 288 Romanya, 530 Gürcü ve 18 Sirp olmak üzere 7.998 rahip yaşamaktadır ${ }^{61}$.

Yarımada'da, 20. yüzyılın ortalarında, din adamlarının sayısı dört bine düşerken, halen 20 manastır bulunmaktadır ${ }^{62}$.

\section{Manastırların Mimarî Özellikleri}

Aynaroz'daki manastırların mimarî özelliklerinin Türk-İslam mimarisine benzemesi dikkat çekicidir. Manastırların Türk-İslam medeniyeti ile bağlantıları, bunların mimarîlerinde kullanılan bazı özelliklerden ve organlardan ibarettir. Manastırların ahşap kısımlarında eski Türk evlerindeki yapı unsurları, cumbalar, geniş saçaklar ve praçollara dayanan geniş çıkmalar vardır. Bazı manastırların avlularında XVI. ve XVIII. yüzyıl üslubunda Türk çeşmeleri de bulunur. Lavra Manastırı'nın avlusundaki şadırvan tamamen Bizans üslubunda yapılmış olmakla beraber kubbe kemerlerini taşıyan dört mermer sütununun başlıkları XVII. yüzyıla ait stalâktitli Türk başlıklarıdır. Bunların 1635 'te bir İstanbul patriği tarafindan gönderildikleri bilinmektedir. Bazı ağaç kilise eşyaları da üstlerindeki oyma veya kakma süslemelerden anlaşıldığına göre XVI-XVIII. yüzyıllara ait Türk sanatlarının örnekleridir. Vatopedi Manastırı kilisesinin 1567 tarihli ağaç kapı kanatları Hıristiyan ustalar tarafından Türk üslubunda yapılmıştır. Yemekhanelerin ahşap tavanları da kaplama tekniği ve şualı göbek süslemeleriyle XVIII-XIX. yüzyıl Türk ev, yalı ve konak mimarisindeki tavanların tam benzeridir $^{63}$.

Aynaroz manastırlarının kiliselerinde karşılaşılan Türk sanat eserlerinin önemli bir grubunu çiniler ve çeşitli kap kaçak teşkil eder. XVII. yüzyılda Hıristiyan müşteriler tarafından İznik çini atölyelerine ismarlanan çinilere Stavronikita,

${ }^{61}$ Musa Kazım, a.g.m., s.1194.

${ }^{62}$ Meral Metin, a.g.t., s.64.

${ }^{63}$ Semavi Eyice, a.g.m., s. 268. 
Pantokratoros ve Lavra manastırlarında rastlanmaktadır. Ayrıca bazı İznik tabakları cephelere yapıştırılmak suretiyle dış süslemede de kullanılmıştır. XVIII. yüzyılın Kütahya çinilerinden ve XIX. yüzyılın Çanakkale tabaklarından da süslemelerde kullanılmıştır. Kutlumusiu Manastırı'nda İznik ve Kütahya çinileri vardır. İviron'da büyük panolar halinde selvilerle süslü çiniler, ayrıca İznik ve Kütahya tabakları bulunmaktadır. Lavra Manastırı'nın dış duvarlarına yapıştırılmış İznik tabakları vardır. Dokhiariu Manastırı kilisesinde ise mihrap kısmında yere döşenmiş olarak İznik çinileri vardır ${ }^{64}$.

\section{Sürgün Mekânı}

Aynaroz her ne kadar Ortodoks mezhebi için din adamı yetiştirilen bir manastır şehri olsa da aynı zamanda bir sürgün mekânı olarak da kullanılmıştır. Manastır şehri olması nedeniyle Aynaroz'un sürgün misafirleri de çoğunlukla din adamlarından oluşmuştur ${ }^{65}$. Sürgüne sebep olan suçlar ise farklılık arz etmektedir. Örneğin, Uşak Kazası'nda mütemekkin Kalinikos isimli rahip, ayini kurallara aykırı yaptığı için Aynaroz adasına sürgün edilmiştir ${ }^{66}$. Yine, aynı dönemde Lofça Kazası Piskoposu Milenos, adam yaralama ve ahaliye kötü davranma suçlarından Filatyos manastırına sürgün edilmiştir ${ }^{67}$.

Sürgün misafirlerinin ağırlıklı olarak din adamı olmasına karşın, başka kesimlerden suçlular da Aynaroz'a sürgüne gönderilmiştir ${ }^{68}$. Örneğin, Bozcaadalı Yorgi Valisodi isimli bir şahıs yakın akrabası bir kızı iğfal suçundan adaya sürgün edilmiştir ${ }^{69}$.

\section{Aynaroz'da Gündelik Yaşam}

\footnotetext{
${ }^{64}$ Semavi Eyice, a.g.m., s. 268.

${ }^{65}$ BOA., C.ADL, Nr.70/4201, Tarih: 28/L/1216 (3 Mart 1802); BOA., C.ADL, Nr.100/6016, Tarih: 06/Ra/1217 (7 Temmuz 1802); BOA, C.ZB, Nr.53/2631, Tarih: 29/Z/1218 (10 Nisan 1804); BOA, C. $A D L$, Nr.44/2654, Tarih:28/C/1226 (20 Temmuz 1811); BOA, A. MKT, Nr.155/36, Tarih:21/Za/1264 (20 Ekim 1848).

${ }^{66}$ BOA. A. MKT, Nr.112/17, Tarih: 21/Ra/1264 (20 Ekim 1799).

${ }^{67}$ BOA. A. MKT, Nr.155/36, Tarih: 21/Za/1264 (27 Şubat 1848).

${ }^{68}$ BOA., C. ADL, Nr.64/3816, Tarih:20/Ca/1214 (20 Ekim 1799); BOA, HR. MKT., Nr.30/5, Tarih:04/R/1266 (17 Şubat 1850.

${ }^{69}$ BOA, HR. MKT, Nr. 201/32, Tarih:21/Z/1273 (12 Ağustos 1857).
} 
Aynaroz'da daha çok keşişler yaşamaktadır. Bilindiği gibi keşişler dünyevi bir takım zevk ve ihtiyaçtan uzak durmaya çalışırlar. Cinsellik, dünya malı, vücut temizliği gibi bir takım ihtiyaçlarını karşılamazlar. Az uyurlar, toplumdan soyutlanıp izdivaya çekilirler. İtaatkârdırlar.

Aynaroz'daki gündelik yaşam da keşişlerin ve diğer din adamlarının özellikleri doğrultusunda şekillenmiştir. Aynaroz'daki gündelik yaşama dair bilgileri bir Amerikalı gazetecinin izlenimleri net bir şekilde ortaya koymaktadır. Amerikalı gazeteci Selanik’ten İstanbul'a gelirken Aynaroz'u duymuş ve güzergâhını değiştirerek Aynaroz'a yönelmiştir. Adada bir manastırda birkaç ay kalarak günlük yaşamı gözlemlemiştir. İzlenimlerini “Asırlardan Beri Kadın Yüzü Görmeyen Bir Yer: Aynaroz'da Papazlar Nasıl Yaşarlar?” başlı̆̆ıyla $\operatorname{aktarm} 1 s ̧ t ı r^{70}$.

Gazetecinin Aynaroz’a yönelik ilk izlenimi, günün modernitesinden oldukça uzak ve şehre ilkel bir yaşam tarzının hâkim olduğu yönündedir. Gazeteci, Aynaroz'daki ilkelliği şu cümlelerle dile getirmektedir. ${ }^{71}$ : "Bugün bile Aynaroz manastırındaki hayatı düşündükçe rüya mı görüyorum diye gördüklerime bir türlü inanamıyorum. Orada hayat, bizim otomobilli, ĕglenceli, zevkli, güzel hayatımızdan o kadar farkl ki insanların bu sefalet ve bu mahrumiyete, bu vahşete nasıl tahammül ettiklerine hayret etmemek mümkün değildir. Oraya girdiğiniz zaman kendinizi Hazret-i İsa zamanında dăglarda yaşayan sahabeler arasında zannedersiniz. Burada otomobil nedir işitmemişler, şimendifer nasıl şeydir görmemişler, kadın nedir tanımamışlar."

Amerikalı gazetecinin bir diğer önemli gözlemi ise, Aynaroz’a kadının girmesinin yasak olduğu konusu ile ilgilidir. Zira yukarıda da değindiğimiz gibi rahip Athanasios 1045 'te Aynaroz'a kadın ve her türlü dişi hayvan, hatta "sakalsız" erkeklerin dahi girmesini yasaklamıştır ${ }^{72}$. Gazetecinin izlenimlerine göre; manastır papazları nezdinde kadınlar, dünya üzerinde şeytanın temsilcisidirler.

\footnotetext{
70 “Asırlardan Beri Kadın Yüzü Görmeyen Bir Yer: Aynaroz’da Papazlar Nasıl Yaşarlar”, Resimli $A y$, C.2, S.9, İstanbul, Teşrin-i evvel 1341, s.24-25.

71 "Asırlardan Beri Kadın...", s.24.

${ }^{72}$ Semavi Eyice, a.g.m., s. 267.
} 
Papazlar, şeytandan kaçar gibi kadınlardan kaçarlar ${ }^{73}$. Amerikalı gazetecinin 19. yüzyıldaki bu tespiti, kadınların 1045'te Aynaroz'a girmesini yasaklayan gerekçe ile aynıdır. Dolayısıyla 1045 yılında kadını her türlü kötülüğün müsebbibi olarak gören zihniyet 19. yüzyıla kadar geçen süreçte değişmemiştir. $\mathrm{Bu}$ yasak geçerliliğini günümüze kadar (2012) korumuştur.

Aynaroz'a kadınların girmesi, muhtemelen, din adamlarında cinsellik duygusunun uyanmasına sebep olacağı düşüncesiyle engellenmiştir. Böylece zinanın önüne geçileceği umulmuştur. Ancak Amerikalı gazetecinin tespitlerine göre bu yasak, söz konusu günahın işlenmesinin önüne geçmeye yetmemiştir. Zira bazı din adamları civar köylere giderek cinsel ihtiyaçlarını buralarda gidermişlerdir ${ }^{74}$.

Manastır papazlarının kilise mûsîkîsinden başka mûsîkî bilmedikleri, gazetecinin bir diğer tespitidir ${ }^{75}$. Dolayısıyla Aynaroz'da tek tip müzik hâkimdir.

Manastır papazları, yılın büyük bölümünde oruç tuttukları için çoğu zaman yemek yemezler, bu nedenle beslenme alışkanlıkları çok zayıftır. Yemekleri ekmek ve zeytinden $^{76}$ veya nadiren köylülerin getirdikleri yiyecek maddelerinden ibarettir. Et, yağ ve balık namına ağılarına bir şey koymazlar. Sadece şarabın, papazlar tarafından çok sevildiği ve tüketildiği bilinmektedir ${ }^{77}$. Zira, manastırların etrafı üzüm bağlarıyla müteşekkildir ve her manastırın çok sayıda mahzeni bulunmaktadır. $\mathrm{Bu}$ mahzenlerden bazıları bilhassa şarap deposu olarak kullanılmaktadır ${ }^{78}$. Şarap mahzenlerine sahip manastırın papazları, hemen her gece içmekte, hatta gündüz bile sarhoş gezmektedirler ${ }^{79}$.

Aynaroz'daki din adamlarının temizlik alışkanlıklarının olmaması, gazetecinin bir diğer tespitidir. $\mathrm{Bu}$ durum ancak dini inançlarla izah edilebilir. Gazetecinin bu

\footnotetext{
73 “Asırlardan Beri Kadın...", s.25.

74 “Asırlardan Beri Kadın...", s.25.

75 "Asirlardan Beri Kadın...", s.25.

76 Aynaroz'da zeytin tüketiminin fazla olması, üretiminden kaynaklanmaktadır. Bir taraftan rahipler kendilerine ait zeytin bahçelerinde üretim yaparken diğer taraftan da Aynaroz Yarımadasındaki birçok köyde zeytin üretimi yapılmaktadır. Bkz. BOA, C. ADL., Nr.17/1030, Tarih 03/Z/1255 (7 Şubat 1840); 1320 Tarihli Selanik Vilayet Salnamesi, s.492.

77 “Asırlardan Beri Kadın...”, s.25.

${ }^{78}$ BOA, A. DVN. KLS.d., Nr.930, Tarih: Receb 1237 (Mart/Nisan 1822).

79 “Asırlardan Beri Kadın...”, s.25.
} 
konudaki tespitleri şöyledir: "Manastır papazları yıkanmazlar. Yıkanmak günah addedilir. Onun için vücutları, sakalları ta uzaktan insanın içini bulandıran derin bir koku ile mesturdur. Dünyada pisliği ta'zîz eden ve bunu dinî bir emir telakki eden insanları gördükten sonra Hıristiyanlı̆̆a acıdım" 80 .

Amerikalı gazetecinin bir diğer tespiti okuma alışkanlığı ve becerisi üzerinedir: “Manastırda Incil'den gayri kitap yasaktır. Bunlar gazete okumaz, dünyada olup biteni merak etmez cahil insanlardır. Başpapaz Yuvakim Efendi bile güçlükle okuyabiliyordu" ${ }^{\prime \prime 1}$.

$\mathrm{Bu}$ tespit ne kadar doğrudur bilinmez, ancak bilinen bir gerçek var ki o da; Aynaroz'un Bulgar milliyetçiliğinin temelinin atıldığı yer olduğudur. Meral Metin de tezinde, Aynaroz'da 15.000 kitabın bulunduğu bir kütüphanenin varlığından bahsetmektedir $^{82}$. Bu tespitler Amerikalı gazetecinin bu konuyu abarttı̆̆ izlenimini doğurmaktadır. Ancak Vraçalı Sofroni hayat hikâyesini anlattı̆̆1 kitabında; din adamlarının okuma-yazma bilmediklerini sık sık vurgulamaktadır ${ }^{83}$. O halde Aynaroz'da geniş bir kütüphanenin var olduğu, ancak okuma-yazma alışkanlığının yaygın olmadığı sonucuna ulaşılabilir.

Din adamları Aynaroz'da üretimin büyük kısmını üstlenmişlerdir. Manastırda papazlar her türlü işlerini kendileri görmüşler, ekmeklerini, şaraplarını yapmışlar, zeytinlerini yetiştirmişler, mantolarını dikmişlerdir. Manastırın işlerini yapmak üzere aralarında iş bölüşümü yapmışlardır. Buna göre kimisi kilercidir, kimisi kapıcıdır, kimisi de hizmetlidir. ${ }^{84}$

\section{Sonuç}

Narlı'nın ifade ettiği gibi; mekânın bizzat kendisi bir ruhtur ve bu ruh, orada yaşayan insanları yavaş yavaş dönüştürmektedir. Bütün değişim ve dönüşüm süreçlerinde her unsur sadece kendi şartları içinde ve kendi diyalektiğine bağlı

\footnotetext{
80 “Asırlardan Beri Kadın...", s.25.

81 “Asırlardan Beri Kadın...", s.25.

${ }^{82}$ Meral Metin, a.g.t., s. 112.

${ }^{83}$ Vraça'lı Sofroni, Osmanlı'da Bir Papaz, Günahkâr Sofroni’nin Çileli Hayat Hikâyesi 17391813, Kitap Yayınevi, İstanbul 2003, s.113.

84 “Asırlardan Beri Kadın...", s.25.
} 
olarak değişmez. Toplumlar yer değiştirdiğinde, insanlar ev değiştirdiğinde ya da kültürel temas ve yitimlerde, hatta sosyal ve siyasal hayata yön veren devletler, devlet anlayışları değiştiğinde, hayatın ana damarlarını besleyen ihtiyaçlar, bakış açıları ve çatışmalar da değişir. Bunun böyle olması insan-mekân ilişkisinin niteliklerini belirler. Elbette mekânın kendi şartları içinde değişmesi ile insanın algıları arasında bir ilişki vardır ${ }^{85}$. Böyle bir değişimden bahsedilememesine karşın, "mekân ve insan birbirini ne kadar etkileyebilir?" sorusuna Aynaroz örneğinden cevap verilebilir. Dinî bir mimarinin hâkim olduğu, kadınların olmadığı ve din adamlarının nüfusun büyük kısmını oluşturduğu Aynaroz'da, insanın mekâna katkısı oldukça büyüktür ve insan, mekânı değiştiren ve dönüştüren bir unsur olarak vardır. 1045 yılında konulan bir yasağın 2011 yılında da devam ediyor olması, fikrimizi destekleyen önemli bir göstergedir. Kadın, mekâna ruhunu katan bir varlıktır. 11. yüzyılda Aynaroz'u bu ruhtan esirgeyen zihniyet, 21. yüzyılda da devam etmektedir. Dolayısıyla burada kadına bakış değişmediği gibi, kadının mekâna yansıttığı ruh da Aynaroz'da eksik kalmıştır.

\footnotetext{
${ }^{85}$ Mehmet Narlı, Şiir ve Mekân, Hece Yayınları, Ankara 2007, s.25.
} 


\section{Bibliyografya}

\section{Başbakanlık Osmanlı Arşivi $^{86}$}

Sadaret Mektubi Kalemi Evrakı (A. MKT)

Bab-1 Asafi Divan-1 Hümayun Gayr-i Müslimler Kalemi (A. DVN. KLS.d)

Cevdet Adliye (C. ADL)

İrade Dahiliye (İ. DH)

Hariciye Nezareti Mektubi Kalemi Evrakı (HR. MKT)

\section{Salnameler}

1299 Tarihli Selanik Vilayet Salnamesi.

1320 tarihli Selanik Vilayet Salnamesi.

1324 tarihli Selanik Vilayet Salnamesi.

\section{Kitap ve Makaleler}

Ahmet Hamdi Tanpınar, Saatleri Ayarlama Enstitüsü, Dergâh Yayınları, İstanbul 2005 .

“Asırlardan Beri Kadın Yüzü Görmeyen Bir Yer: Aynaroz'da Papazlar Nasıl Yaşarlar”, Resimli Ay, C.2, S.9, İstanbul, Teşrin-i evvel 1341, ss.24-25.

Evliya Çelebi Seyahatnamesi, Cilt: 8, Hazırlata: Seyit Ali Karaman vd., YKY, İstanbul 2003.

George Henry Townsend, A Manual of Dates: a Dictionary of Reference, Frederick Warne\&Co., London 1867.

\footnotetext{
${ }^{86}$ Belgelerin dosya ve gömlek numaraları dipnotlarında belirtilmiştir.
} 
G.W. Samson, Elements of Art Criticism, Philadelphia 1967.

İlber Ortaylı, Imparatorluğun En Uzun Yüzyılı, İletişim Yayınları, İstanbul 2006.

Mehmet Narlı, Şiir ve Mekân, Hece Yayınları, Ankara 2007.

Meral Metin, XIX. YY.da Osmanll Devleti'nde Aynaroz Adasl, Aynaroz Ruhbanları ve Rum İsyanları, (Yayımlanmamış Yüksek Lisans Tezi), Erciyes Üniversitesi, Sosyal Bilimler Enstitüsü, Tarih Anabilim Dalı, Kayseri 2010.

Musa Kazım, “Aynaroz'un Tarihçesi”, Tarihi Osmanî Encümeni Mecmuası, Cilt 4, 19.Cüz, 1 Nisan 1339, ss.1194-1199.

Mustafa Balcı, Selanik Düştü, Selanik'in Kaybediliş Öyküsü, Kesit Yayınları, İstanbul 2010.

M. Pierce, The Cottage Cyclopedia of History and Biography, Case Lockwood\&Brainard, Hartford, Cann, Chicago 1969.

Önder Kaya, Tarihin Gör Dediği, Yeditepe Yayınları, İstanbul 2006.

Ruhi İnan, "Karşılaştırmalı Sosyo-Kültürel Bir Mekân Poetiği: Akif' in Mahalle Kahvesi ve Esâfil-i Şark", Uluslararası Mehmet Akif Ersoy Sempozyumu (11-13 Mart 2011, Balıkesir) Bildiriler Kitab1, Balıkesir 2011, ss.241-249.

Semavi Eyice, “Aynaroz”, Türkiye Diyanet Vakfı İslam Ansiklopedisi (DİA), C.4, İstanbul 1991, ss.267-269.

Vraça'lı Sofroni, Osmanlı'da Bir Papaz, Günahkâr Sofroni'nin Çileli Hayat Hikâyesi 1739-1813, Kitap Yayınevi, İstanbul 2003. 